\title{
8. How the Pollsters Called the Horse Race: Changing polling technologies, cost pressures, and the concentration on the two-party-preferred
}

\author{
Murray Goot
}

For students of public opinion polls - more particularly, students of the pollsters' attempts to monitor voting intentions and predict election outcomes - three features of the 2013 campaign stood out and, in assessing the performance of the polls, it is on these features that this chapter will dwell: the substantial increase in the number of polling organisations involved as new pollsters sought to publicise their skills to potential clients; the spread of 'robo' polls, a development that allowed the press to recover its pre-eminent position as the sponsor of pre-election polls; and the proliferation of polling technologies as pollsters grappled with the challenges posed by voters shifting from landlines to mobile phones and the internet. Shaping this changing landscape were not only the availability to pollsters of newer, cheaper technologies, but also the cost pressures faced by the press, and the increasing focus in the media on the two-party-preferred vote - a way of framing the race that reduces everything that matters to a single number and with it the risks involved in calling the result.

No fewer than nine firms produced estimates of how the race was going and/or of the final result; in 2010 the corresponding figure was six. Eight firms produced estimates of the vote nationwide, five also produced estimates of the votes in a number of the marginal seats, while the ninth (JWS Research) restricted itself to estimating the outcomes in some of the marginals. Three of the firms were long-established (Newspoll, Nielsen, and Roy Morgan Research), three had been conducting election polls for much shorter periods (Galaxy, Essential Research, and JWS), and three were new to election polling (AMR, Lonergan Research, and ReachTEL). As the last of the companies operating out of the smaller states was sidelined - this time the Patterson Research Group, which had polled for The West Australian at federal elections since 1990 and for The Canberra Times since 2007, was not asked to poll for any newspaper - two of the newer companies along the eastern seaboard spread their reach: Galaxy, which for the first time serviced all News Corp's metropolitan tabloids, and ReachTEL, which polled not only for News 7 (something it had done since March 2010), but also for Fairfax Media, the Mercury, and the Launceston Examiner. In-house polling 
also disappeared with The Advertiser's polling in South Australia being taken over by Galaxy. As usual, the polls focused on the election for the House of Representatives; only Lonergan offered any sort of guide to the race for the Senate.

A second feature was the nature of the technology used to monitor the distribution of party support in the most marginal of seats that were polled. Instead of staying with CATI (Computer Assisted Telephone Interviewing), newspapers hired firms that ran 'robo-polls' - telephone polls based on Interactive Voice Recognition software where respondents listen to pre-recorded questions and then key-in their answers (Goot 2014). Four of the five firms hired to run marginal seat polls - Galaxy, JWS, Lonergan, and ReachTEL-used 'robos'; in 2010 only JWS had used this technology. The switch to 'robos' represented a big cost saving for newspapers under severe financial pressure from declining revenues. In the marginals, only Newspoll stuck with CATI. The low cost of 'robos' even enticed one of the television networks, News 7, to run short polls. Newspapers, however, continued to commission national polls that used CATINewspoll, commissioned by The Australian; Galaxy, commissioned by News Ltd to service its metropolitan mastheads; and Nielsen, for Fairfax Media (Age, Sydney Morning Herald, and Australian Financial Review). As usual television stations added to the drama of election night by commissioning election-day polls (Newspoll for News Ltd's Sky News) or exit polls (Galaxy for Channel 9; Roy Morgan for Channel 10).

The shift to 'robo-polls' also shifted the balance of initiative in the generation of poll data for public consumption away from polls paid for by market researchers - a feature of the 2010 election (Goot 2012: 91) - back to polls commissioned by the press. JWS conducted a round of marginal seat polls for the Australian Financial Review, Lonergan did some polling for the Guardian Australia online, and ReachTEL ran marginal seats polls for Fairfax, the Mercury and the Launceston Examiner. Galaxy, Newspoll, and Nielsen maintained their relationship with News Ltd and the Fairfax press. Four companies paid their own way: AMR, Essential and Morgan (all of which conducted national polls), and JWS (which polled in the marginals). Compared to 2010, four independent pollsters represented an increase of one, but in relative terms four was a decrease. Morgan posted the results of its polling on its website, and distributed the results to some 12,000 email addresses as well as to newspapers and television stations. Essential published its results online via Crikey and distributed them to 1,000 email addresses, including numerous media outlets. JWS published all its findings online, regardless of whether they had been commissioned by the press or paid for by JWS.

A third feature was the range of the data gathering techniques that pollsters deployed. As well as variety across the industry, the campaign was marked by the 
use of an increasing range of technologies within particular firms. Morgan used SMS for its exit poll but during the campaign it used mixed modes - varying combinations involving face-to-face interviews, landlines, text messaging, and questionnaires posted online. Galaxy used telephone interviewers for its national polls, face-to-face interviews for its exit poll, and-to remain commercially competitive-'robo-polls' in the marginals. Newspoll, which ran a day-of-the-election poll in selected marginals, used CATI throughout; together with Nielsen it stuck to the technology it knew best, a technology it continued to trust and one the newspaper it serviced was prepared to pay for. Essential ran its polling online. JWS, Lonergan, and ReachTEL ran 'robos' in marginal seats through landlines. Lonergan switched to mobiles for its final 'robo' - the only poll it conducted nationwide.

Almost all the polls came very close to predicting the national two-partypreferred. Even if we allow for the fact that their estimates, as it turned out, were based on a mistaken understanding that preferences would split in much the same way as they had done in 2010, the polls did much better than their long-term average. Inevitably, of course, there was an order of merit. For the most part, however, only someone who knew nothing about sampling variance would attach much importance to the differences. Nonetheless, the polls generally over-estimated Labor's share of the two-party-preferred, something they have done for a number of elections.

While commentators were happy with the polls' performance in predicting the national outcome, some expressed concerns about the reliability of the pollsparticularly the 'robo-polls' - in individual seats where results at odds with the national polls had raised unnecessary hopes or unjustified alarm. This was especially true in relation to the Prime Minister's seat of Griffith. Closer examination suggests that the performance of the 'robos' in the marginals was not significantly worse than the performance of the polls that used CATI, with most polls suffering from small sample sizes, the worst errors coming from polls of all descriptions taken early in the campaign.

Less impressive than the polls' estimates of the two-party-preferred were their estimates of first preferences. Noteworthy, too, was the relatively poor performance of polls that sampled mobiles, polls conducted on the day of the election, and polls that attempted to estimate the outcome in the Senate.

\section{Predicting the house vote nationwide}

For once, the question of whether the national polls had got it right-even the question of which of them had done best - did not loom large in the postelection wash-up. There seemed to be general agreement that most of these polls 
had got it right. At the end of the night, Simon Jackman, whose comments on the polls appeared regularly in the Guardian Australia online, thought the national polls had 'fared pretty well', especially if one allowed for a further shift towards the Coalition once the pre-poll and postal votes were counted (Jackman 2013). On the Monday following the election (9 September), William Bowe anticipated that a drift to the Coalition in late counting would bring the results into line with his BludgerTrack poll, built by aggregating the national polls (Bowe 2013a). In Crikey, Matthew Knott also noted that 'most of the big pollsters appear to have performed well' (Knott 2013).

In each of these assessments the measure of accuracy was the polls' approximation to the national two-party-preferred - not, as is the case everywhere else in the world, the average error in estimating the parties' first preferences or the gap between the first preferences for the government and the first preferences for the opposition. The two-party-preferred is relatively easy to approximate especially when many pollsters are attempting to do it. The leaking of party polls suggesting Labor was headed for a resounding defeat may have helped as well. Judgments about how well the polls had done were certainly helped by the fact that none of the pollsters dared to predict the two-party-preferred to the first decimal place - as Newspoll had done in 2010. Such a practice is likely to end in tears or in the pursuit of something even more absurd - that is, predictions accurate to the second decimal point, an attempt to ratchet-up the competition trialled by Morgan in 2010 (Goot 2012: 88). Assessments of the polls in the Poll Bludger and Crikey were based on how the polls had performed nationally, not on how well they had predicted the outcomes in marginal seats; only the Guardian Australia alluded to that. Assessments were also restricted to how well the polls had estimated the vote for the House of Representatives; their performance in relation to the Senate was ignored.

Usually, several polling organisations claim to have produced the most accurate poll. This time there was only one. Roy Morgan Research, which entered three horses in the race-its penultimate pre-election day poll, its final pre-election day poll, and an SMS exit poll - declared its exit poll the winner. In a statement issued on 9 September, Morgan claimed 'The Roy Morgan-Channel 10 SMS Exit Morgan Poll' proved 'the most accurate measure of the voting intentions of Australian electors' (Roy Morgan Research 2013a). At that stage of the count, Morgan's two-party-preferred was just 0.1 percentage points outside the Australian Electoral Commission's (AEC) figures. 'In addition', Morgan claimed, it had produced the only poll to show the surge in support for the Palmer United Party' (this wasn't true) and to have predicted that Clive Palmer 'could' win the seat of Fairfax, something Morgan had done shortly before the election but without furnishing any figures (Roy Morgan Research 2013a). John Stirton from Nielsen - one of the few polling firms not to have polled in single seats - 
noted how poorly the polls had fared in individual seats where the polling, he insisted, had 'often' been 'out of whack with reality'; of the 55 polls conducted in single seats Labor 'should have been in front on 25', he said, not just the 12 in which the AEC had them leading at the close of counting (Allard 2013).

Not all the newspapers commented on the polls, notwithstanding that all had published polls and almost all, at some stage, had commissioned them; only one metropolitan daily, The West Australian, failed to commission any polling. In the Australian Financial Review, Edmund Tadros (2013) overcame his reluctance to pass judgment - 'polling', he intoned, 'is not predictive' — to declare Morgan 'the most accurate of the pre-election polls', followed by Galaxy, ReachTEL, and Newspoll. Least accurate was Lonergan's 'robo-poll' conducted via mobiles. In the marginals, he argued, 'robo-pollster' JWS published by the Financial Review had 'performed the best, picking the eventual winner in more than 80 per cent of the seats it surveyed'. While another robo-pollster, ReachTEL, would also 'be pleased with its performance', Tadros suggested Newspoll's efforts in the marginal seats were '[l]ess successful' with fewer than 70 per cent of its polls foreshadowing the eventual winner. The record of the Galaxy poll in marginal seats passed without mention. At the Daily Telegraph, which had published the Galaxy poll and whose stable mate The Australian had published Newspoll, the editor-at-large saw things quite differently. 'In the battle of the polls', John Lehmann declared, 'Galaxy and Newspoll dominated' (Lehmann 2013). Here the marginal seat polling of both Galaxy and Newspoll passed without mention. In the Age, which had published the Nielsen poll, Tom Allard (2013) noted, with a sense of schadenfreude, that 'a slew of polls of individual electorates' had 'suggested a diabolical outcome for Labor, including Mr Rudd losing his seat of Griffith and a wipeout in western Sydney'. Allard singled out the Australian, relying on Newspoll, for predicting that 'Labor would lose between 12 and 16 seats in NSW and between four and six in Queensland'. About the performance of ReachTEL, commissioned by the Age to poll four Victorian marginals, he said nothing, notwithstanding that ReachTEL had substantially over-estimated (Melbourne) or under-estimated (Corangamite) Labor's first preference vote in two of the four.

All three commentators focused on the pre-election polls; the Morgan exit poll, the Galaxy exit poll, and the election day Newspoll did not rate a mention. In arriving at the percentages of hits and misses none of the three commentators attempted to calibrate degrees of difficulty. Only Lehmann cast an eye over the first preferences. If he judged Galaxy's performance best against the twoparty-preferred, he judged Newspoll 'the most accurate in primary votes'. He discounted Morgan, which had done better on the two-party vote than Galaxy, because it 'was the least accurate of the major polls on primary votes'. Nielsen, he noted, had 'overstated The Greens primary vote' (Lehmann 2013). 
Written shortly after the election, and well before the counting of the 'declaration votes' - absentee and postal votes, of which there were estimated to be over 3.5 million - these judgments of the polls' performance were premature at best, exercises in corporate propaganda at worst. Day-after-the-election judgments, written by journalists against tight schedules and with incomplete data, usually are.

Judged against the final two-party-preferred nationwide- 53.5 per cent for the Coalition, 46.5 for Labor - almost all the pre-election estimates were remarkably close. Leaving aside the last-minute Lonergan poll, the spread across the other seven polls was just 2 percentage points, with the Coalition expected to win between 52 and 54 per cent of the two-party vote (Table 1). For two of the three CATI polls - Nielsen (which had provided pre-election estimates of the twoparty-preferred since 1993), and Galaxy (which had done so since 2004) - the results were their best ever. For the third, Newspoll, the size of its error was half its 20-year average (Goot 2012: 95).

Nonetheless, the polls generally over-estimated Labor's two-party-preferred. While two polls had the Coalition winning 54 per cent of the two-partypreferred, five polls had the Coalition winning 53 per cent or less - the Lonergan poll, with a 50.8 per cent estimate, undershot the mark by a sizeable margin (Table 1). Had the pollsters allocated preferences on the basis of how they were going to be distributed in 2013 rather than on the basis of how they were distributed in 2010 - the typical though not universal approach adopted by the various polling companies - the estimate of the Coalition's two-party-preferred, according to Bowe (2013b), would have been 1 percentage point less. In other words, the polls might have over-estimated Labor's two-party-preferred by an even bigger margin. Moreover, almost every poll might have over-estimated it. Based on this finding, Bowe argues against Morgan's claim to have estimated the two-party-preferred accurately. However, Morgan stands out precisely for having allocated preferences according to how respondents said they would allocate them (53.5:46.5). Indeed, Morgan openly disparaged other pollsters for assuming preferences would be allocated according to the 2010 pattern; on Morgan's own data this would have produced a two-party-preferred of 54.5 to 45.5 (Roy Morgan Research 2013b). Nielsen calculated the likely distribution (54:46) if preferences were allocated according to the 2010 pattern; it also recorded, though it didn't report, how respondents said they would allocate them (53:47-Nielsen 2013). Both the Morgan and unpublished Nielsen figures tell the same story - a story that Bowe's arithmetic would subsequently confirm. 

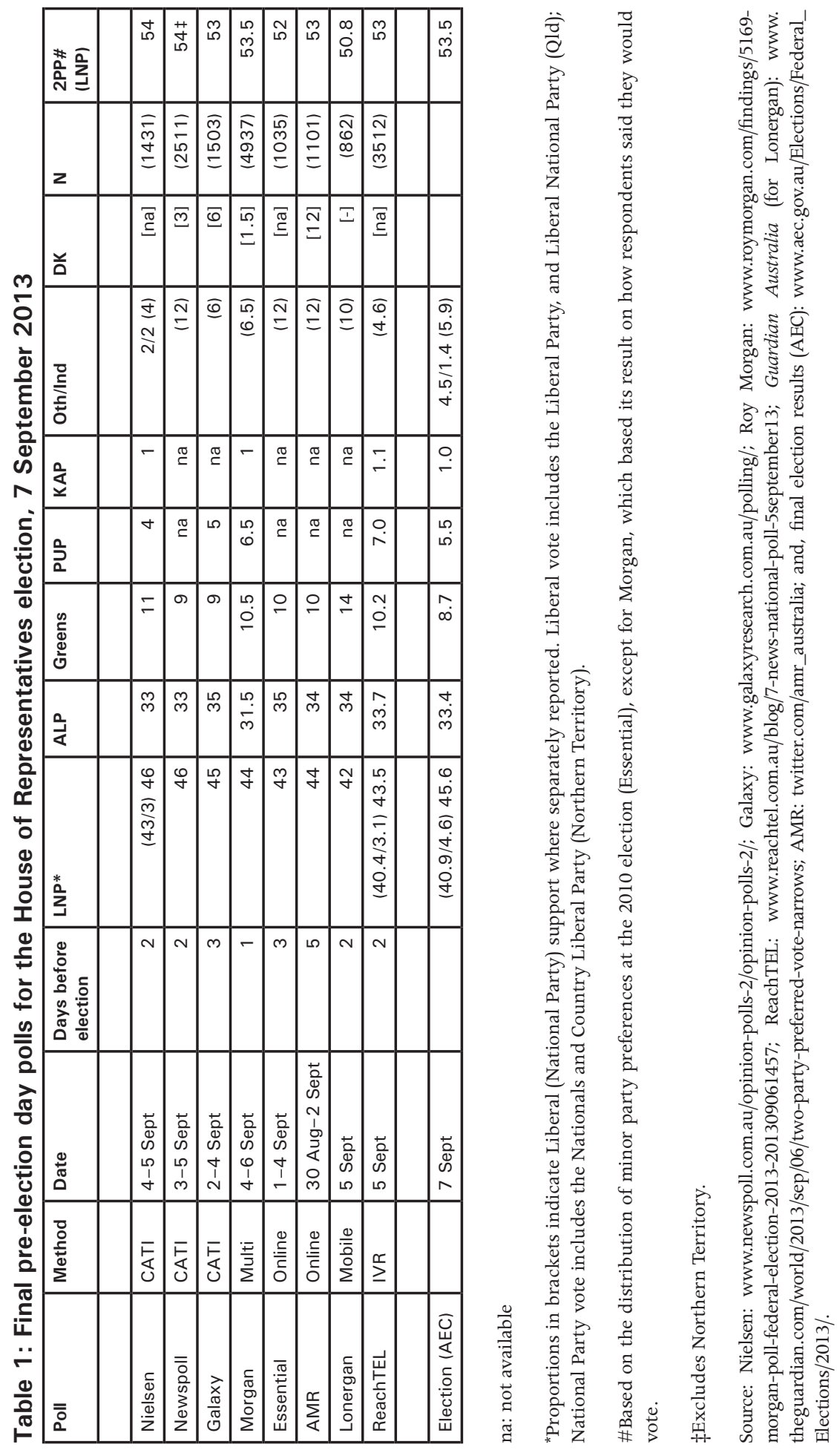
The tendency of the polls to over-estimate Labor's two-party-preferred charted a familiar pattern. In 2010, six of the seven polls under-estimated the Coalition's share of the two-party-preferred (Goot 2012: 91). In 2007, four of the six polls under-estimated it (Goot 2009: 125), and in 2004 four out of the six polls did so (Goot 2005: 60). Before that the pattern was more mixed. Historically, the tendency to over-estimate Labor's two-party-preferred has been a feature of some polling organisations more than others, of Morgan in particular and more recently of Essential. Given the proliferation of polling organisations and approaches to polling in recent years, the study of 'house effects', first undertaken in 2004 by Jackman (2005), needs to be updated.

Meanwhile, a comparison of first preferences tells a less flattering story about the accuracy of the polls. If we compare the polls' estimates of the votes for the ALP, Coalition, Greens, and Others with the votes actually recorded the median error was roughly three times as large (1.4 percentage points) as the twoparty-preferred error (0.4 percentage points). Every poll, including Morgan, over-estimated the vote for the Greens. Few polls, Morgan among them, underestimated the Labor vote (Table 1). Compared with the polls' order of merit on the two-party-preferred, the order of merit on first preferences looks quite different. The poll that scored best was Newspoll (average error 0.4), followed by AMR and Galaxy (1.0), Nielsen and ReachTEL (1.1), Essential (1.5), and Morgan (1.7), with Lonergan (3.0) a distant last.

We get a slightly different story if instead of looking at the estimates that every poll generated we look at the estimates that each poll generated-some polls having estimated separate results for the Liberal and National parties, or disaggregated the results for the Palmer United Party and/or Katter's Australia Party. Of the three polls that disaggregated their estimates, Morgan (average error 1.1 percentage points) and ReachTEL (1.0) did better on this measure, while Nielsen (1.4) did worse. The under-estimate of the National Party vote, as regular as it is predictable, may be a special case (see Aitkin 1982: 188-90)- few of the pollsters even reported it.

\section{Exit polls}

'I know of few things more pointless', Mark Textor, the Liberal Party's pollster, tweeted on the last day of the campaign, than '[e]xit polls on votes'. 'Wait a few hours', he advised, 'seriously' (Textor 2013). For someone wanting to know the outcome of the election and nothing more, the truth of Textor's remarks could hardly be gainsaid. However, exit polls on election day are not much different from polls conducted in the last days of the campaign: they are undertaken not just to satisfy the public's interest in knowing the outcome of the election ahead 
of the official results but also in the hope of demonstrating the abilities of pollsters to forecast the results. These twin objectives - satisfying public curiosity and promoting the profile of particular firms - ahead of official announcements also characterise estimates by private bodies of inflation, unemployment, and likely movements in interest rates.

Of the two exit polls released on the day, Morgan's was the only one that relied on respondents' texting their decision after they had voted. It had the biggest sample, and almost certainly the best geographical spread. Preliminary figures had gone to air on Channel 10 at around 1 pm AEST and were updated every two hours. Galaxy conducted an exit poll, face-to-face, for Nine News with half the number of respondents Morgan mustered. Its interviewing was confined to just 27 polling booths across Australia, in metropolitan and non-metropolitan areas, covering 'marginal seats, reasonably safe seats and very safe seats' (pers. comm.). Its results were tweeted at $5.51 \mathrm{pm}$ (YouDecide9 2013). Crosby/Textor also conducted an exit poll for the Australian Petroleum Production and Exploration Association with 400 respondents drawn from 20 seats in New South Wales and eight seats in Queensland. The poll was designed to measure the impact of particular issues rather than to forecast the outcome, and no results were released on the night (Tasker 2013).

In addition to the exit polls, Newspoll conducted a Day of the Election poll across Labor marginals in New South Wales (10 seats) and in Queensland (eight seats), drawing as many respondents from the Prime Minister's seat of Griffith as it did from all the other Queensland seats combined. Newspoll had polled all 18 seats for The Australian during the campaign. The results went to air on Sky News at 4 pm (AAP 2013), two hours before the polls closed in eastern Australia and five hours before the polls closed in Western Australia.

Morgan's poll, once the final figures were in, was not quite as accurate a measure of the two-party-preferred as its final pre-election poll turned out to be. Nonetheless, it did very well - off by just 0.5 percentage points. Galaxy, off by 1 percentage point, was less accurate. Newspoll, by contrast, did not do well. Matching its figures to the final figures in the seats in which it polled reveals an error of 3.5 percentage points - easily the biggest error among any of the polls, including the Lonergan mobile poll conducted just before the election (Table 2). 


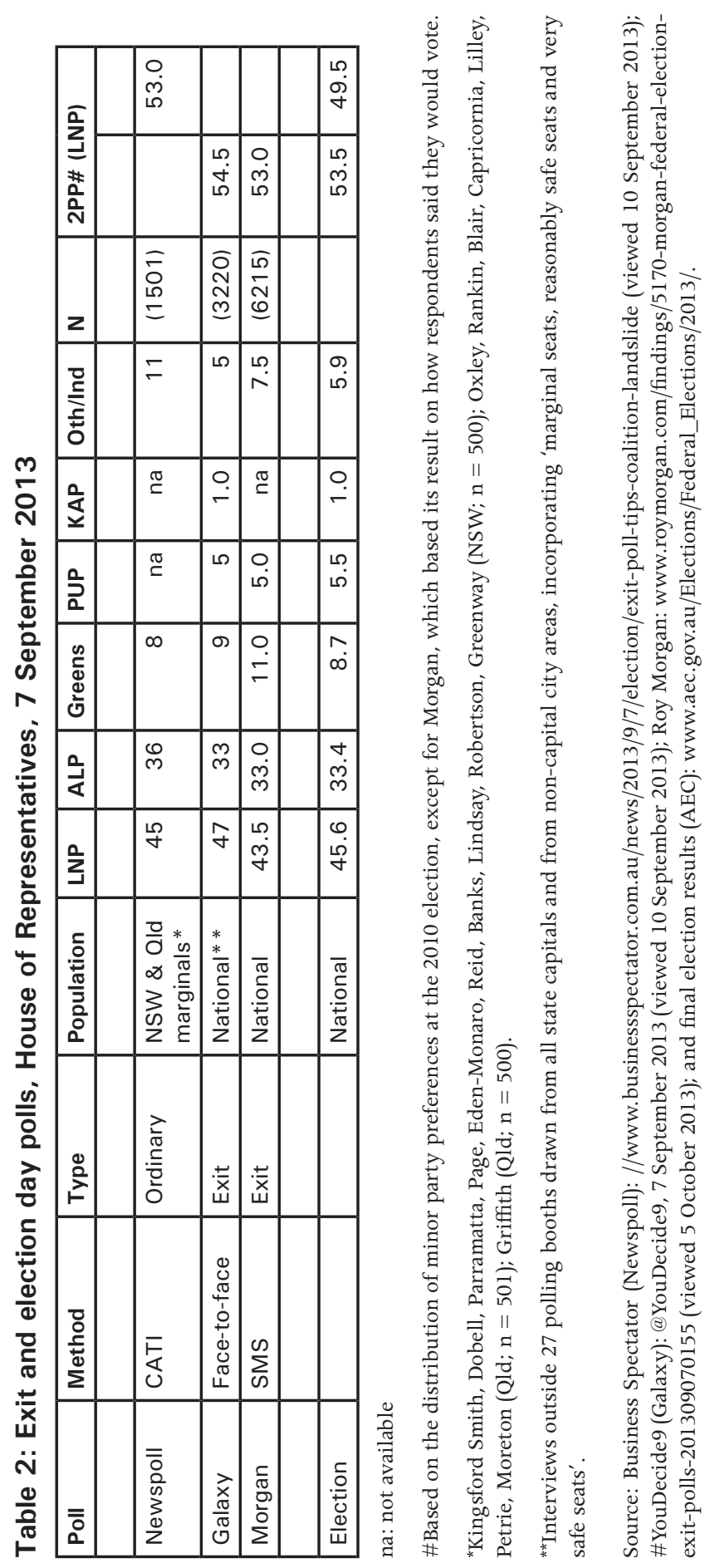


Again, things look different if instead of focusing on the two-party-preferred we look at the estimates that the polls generated for the individual parties. On this measure, Galaxy with an average error of 0.6 percentage points for five parties (plus Others) eclipsed Morgan whose average error was 1.2 percentage points for four parties (plus Others). But the worst poll was Newspoll with an average error of 3.6 percentage points for the three parties (plus Others). Newspoll's main sources of error were the Labor vote, which it under-estimated by a massive 6.7 percentage points, and the vote for the minor parties, which it over-estimated by 4.3 percentage points. The errors were similar in both News South Wales and Queensland.

\section{Marginal seats}

Polling in marginal seats started early, involved an unprecedented number of firms, and was dominated - measured by their number if not by their impactby 'robos'. Galaxy polled in 20 seats, ReachTEL in 14, JWS in 13, and Lonergan in four; all used 'robos'. Newspoll, the only firm to use CATI, polled in 32 seats. With one exception (ReachTEL, which polled twice in Bass), no firm polled any seat more than once. On election day, Morgan came out with predictions for every seat in the country. These were based on questionnaires administered by CATI, via SMS, and online.

Some 25 polls were conducted in the first or second weeks of the campaign, 19 in week three, and 21 in week four (two straddling week three), and just one in week five. Focusing their efforts on the first two weeks helped the companies least well-known-JWS, Lonergan, and ReachTEL-become talking points. Concentrating on weeks three and four meant Galaxy and Newspoll did their most intensive polling as interest in the election built. With relatively few seats (18 of the 55) attracting the attention of more than one pollster-or, more to the point, the interest of more than one client - it was difficult for pollsters to ponder their results in the light of other polls and to contemplate whether, as a result, they might adjust them. By not polling individual seats in the last week - again, based on decisions made mostly by newspapers and television stations not by the pollsters - the polling companies could avail themselves of the defence, if their polls erred, of 'a late swing'.

The seat most frequently polled was Griffith (Queensland). Held by Kevin Rudd by what should have been a reasonably safe margin (8.5 percentage points twoparty-preferred), Griffith attracted five polling organisations. ReachTEL (5 August) noted an anti-Labor swing of 4 percentage points two-party-preferred early in the campaign when Labor was looking not just to hold on to the seats it already held but to win additional seats in Queensland. Lonergan (21 August) 
and Newspoll (21-22 August) caused an even greater stir by suggesting that Rudd was actually trailing his Coalition opponent and former Australian Medical Association president Bill Glasson, 48:52, the two-party-preferred reported by both polls. Galaxy (29 August) had Rudd back where ReachTEL had him. JWS (30 August) had Rudd doing almost as well as in 2010.

The results of the polls, especially those in Griffith, generated controversy. Much of it centred on the deployment of 'robos'. How did the 'robos' fare? While most of the seats went the way these polls pointed, about one in five did not. Of the 20 seats polled by Galaxy, two (Werriwa and Greenway in New South Wales) didn't fall as Galaxy suggested they might, while another two (Barton in New South Wales, and Hindmarsh in South Australia) were lost despite the figures suggesting Labor might hang on to them. Two of the 13 seats polled by ReachTEL (McMahon and Kingsford Smith in New South Wales) didn't fall as it suggested they might. And three of the 13 seats polled by JWS (McMahon; McEwen in Victoria; Lilley in Queensland) were retained by Labor, not lost as the JWS polls suggested might happen. With Rudd holding on in Griffith, one of the four Lonergan polls also proved a poor bet.

Even where the 'robos' successfully picked the winner, their estimates were sometimes out substantially. As well as pointing to the likelihood of Labor losing two seats it actually retained, Galaxy either under-estimated (Blair) or overestimated (La Trobe and Perth) Labor's two-party-preferred by 3 percentage points or more. The ReachTEL figures proved even less reliable. In addition to suggesting that Labor would lose two seats that did not change hands, it underestimated Labor's two-party support by at least 3 percentage points in Blaxland and Bennelong (NSW), as well as in Braddon, Franklin and Lyons (Tasmania). JWS under-estimated Labor's two-party vote in Lindsay (NSW), Aston (Victoria) and Forde (Qld) by 4 to 6 percentage points, while over-estimating it in Griffith. Lonergan, which did not calculate a two-party-preferred except in Griffith, over-estimated the Liberal or LNP first preferences in both Lindsay and Forde by 13 percentage points. What polling didn't detect in seats like these was the late surge in support for minor parties.

Newspoll doesn't appear to have done any better. It did well in Forde, but in Griffith it under-estimated Labor's two-party-preferred by nearly 5 percentage points. In Lyne, where Newspoll did not calculate a two-candidate-preferred (National versus Independent), it under-estimated Labor's first preference vote by 5 percentage points, and in New England it over-estimated Labor's vote by 12 percentage points. These were its only single seat reports. Most of the seats Newspoll surveyed were in clusters and reported as a group. Across the three Victorian seats it polled, the average two-party vote Newspoll reported turned out to be very close to the final figure. Across two groups of Queensland seats - a group of seven held by Labor, and a group of eight held by the LNP-Labor's 
two-party-preferred was 3 or 4 percentage points greater than Newspoll's estimate. In its cluster of five western Sydney seats, Newspoll under-estimated Labor's two-party-preferred by nearly 7 percentage points, though in what the Australian called Labor's 'coastal' seats - five seats stretching from Page in the north of New South Wales to Eden-Monaro in the south of the state-its underestimate was a more respectable 2 percentage points.

Regardless of mode - 'robo' or CATI - sample sizes in individual seats were generally modest. Galaxy recorded between 548 and 660 interviews per seat (an average of 577); JWS between 482 and 757 (an average of 589); and ReachTEL between 541 and 860 (an average of 631). Newspoll, in its single-seat polls, interviewed between 500 and 504 voters; in three of its cluster polls (polls across three, five or seven seats) it conducted 800 interviews, while in its other polls it conducted either 1,106 interviews (five seats) or 1,832 interviews (eight seats). Only with Lonergan, which recorded between 958 and 1,160 interviews per seat (an average of 1,031), were the numbers markedly better. The contrast with the final national polls is striking. Nationally, Lonergan $(\mathrm{n}=862)$ sampled fewer than 1,000 voters; Essential $(\mathrm{n}=1,305)$, AMR $(\mathrm{n}=1,101)$, Nielsen $(\mathrm{n}=$ $1,431)$, and Galaxy ( $\mathrm{n}=1,503)$ sampled more than 1,000; Newspoll ( $\mathrm{n}=2,511)$, ReachTEL $(n=3,512)$ and Morgan $(n=4,937)$ sampled many more (see Table 1$)$. The media drew little, if any, attention to what small or large samples implied about the reliability of the results.

Typically, it was in New South Wales where the 'robos' were widest of the mark. This was true of: JWS, which polled there as well as in Victoria and Queensland; ReachTEL, which polled in all these states as well as in Tasmania; and Galaxy, which polled in every state except Tasmania. One reason why the New South Wales results were wider of the mark than polls elsewhere is that in New South Wales they were taken relatively early. There, the last of the JWS and ReachTEL polls were conducted in week two and the last of the Galaxy polls in week three of the five-week campaign. For Newspoll, the worst single set of seats was also in New South Wales. Overall, however, there wasn't much to choose between Newspoll's performance in New South Wales and its performance in Queensland. In both states, Labor did distinctly better in its marginal seats than Newspoll had suggested.

In addition to reporting its results, Morgan released a set of seat-by-seat predictions. These it derived from its final (mixed-mode) sample of 4,937 respondents - a sample that yielded, on average, just 33 respondents per seat. Morgan's predictions proved less than perfect. In New South Wales, two of the seats predicted to be Liberal-National Party gains (Greenway and Parramatta) failed to change hands, while three of the seats Morgan tipped Labor to hold (Barton, Eden-Monaro and Page) did change hands. In Victoria, the Liberals lost Indi, a seat Morgan expected the party to hold. In Queensland, the LNP did 
not take Blair, Lilley or Moreton from Labor, each of which Morgan predicted would fall; Morgan did not foresee the fall of Fairfax notwithstanding its postelection boast about being 'the only poll ... to predict Clive Palmer could win the seat'. In South Australia, Morgan thought Labor would hold Hindmarsh but it didn't. In Tasmania, Morgan had Labor holding Bass, Braddon, and Lyonsall of which were lost to the Liberals. And in the Northern Territory, Morgan had the Coalition winning Lingiari, a seat where Labor held on (Roy Morgan Research 2013c).

After the election, the fact that none of the polls, 'robo' or otherwise, paraded their prowess at measuring the vote in individual seats should have come as no surprise. Fortunately for its reputation, none of the post-election commentary registered Morgan's predictions let alone the sample sizes on which they were based.

\section{The senate}

In 'horse race' journalism, the Senate finishes a very long last. The political race that stops the nation is the race for the House of Representatives, the race to win government, and the race to be prime minister. Polling for the Senate requires large samples in every state. As with polls in marginal seats, respondents need to be given a list of the parties that are running, or at least a list of the parties that are likely to be in contention. This time, the proliferation of parties made the mechanics of polling for the Senate harder than ever. Notwithstanding this, and the difficulty of calling the last two of the six places in most states, one pollster had a go - not accidentally, perhaps, the one with no previous experience of this most hazardous of undertakings.

In its final poll, conducted via mobiles on 5 September, Lonergan included a question on the Senate vote. The results: 40 per cent for the Coalition, 29 per cent for Labor, and 16 per cent for the Greens, with eight per cent for other parties. Lonergan's figures didn't add up to 100, presumably because the proportion 'undecided' was left out. If we exclude the 'undecided' and redistribute the percentages, the Coalition was on 43 per cent, Labor on 31 per cent, the Greens on 17 per cent, with 'others' on 9 per cent. None of Lonergan's figures were disaggregated by state; with a sample size of just 862 any such division would have been foolish. The results came hedged with a warning. The 'actual Senate vote', Lonergan cautioned, 'has tended to differ from the self-reported voting intention figures in polling, possibly because it is very difficult to convey the complexity of a Senate voting form over the telephone' (Taylor 2013).

The Lonergan poll proved less accurate than any other poll conducted during the campaign. Although its estimate of the Labor vote was close to the mark, it 
over-estimated the Coalition vote by over 5 percentage points, and the Greens by more than 8 percentage points. There was a corresponding under-estimate of the vote for 'others' of nearly 15 percentage points. The average error for the Coalition, Labor, the Greens and others exceeded 7 percentage points.

Essential had ventured into this territory in January and February, building a sample of sufficient size over a number of weeks to enable it say something about Senate support in each of the states, except Tasmania (Bowe 2013c). The sort of figures generated by this poll helped support early views about the likely Senate outcome with speculation about the prospects of the Shooters and Fishers as well as the Christian Democratic Party in New South Wales, the possibility of another Democratic Labour Party senator from Victoria, the strength of Katter's Australia Party in Queensland, and how well Nick Xenophon might do in South Australia. Outside of Western Australia, micro parties did not yet loom as any kind of possibility, and the Palmer United Party (PUP) had yet to emerge.

When Gary Morgan predicted, four days before the election, that PUP 'may take a spot in the Senate', he appears to have been relying on polling data for the House not the Senate. He was also focusing on Queensland where his polling had the PUP, on average, doing twice as well as anywhere else (Roy Morgan Research 2013a). Like everyone else, Morgan under-estimated the party's performance. The PUP didn't only win a Senate seat in Queensland - it also won a seat each in Tasmania and Western Australia, where Palmer's candidate Zhenya Wang won a Senate seat after an appeal to the Court of Disputed Returns (High Court) resulted in an April 2014 re-election.

\section{Conclusion}

The proliferation of polls, and the rise of 'robos', are related. So, too, are the proliferation of polls and the availability of respondents online. Compared to the cost and speed of face-to-face polls, or even CATI, 'robos' have obvious appeal not least to newspapers wanting to sponsor polls but finding the funds to do so increasingly difficult to come by. This is especially true where the data newspapers - and television stations - mainly want, or the only data they can afford are data on voting intentions (Goot 2013).

To have the performance of the polls judged against the two-party-preferred rather than the average error per party is a further incentive to the proliferation of polls since the risk of getting the result of the two-party-preferred wrongnot in the sense of calling the wrong winner but in the sense of under-estimating or over-estimating the winner's margin - is less than the chances of error in estimating the vote for a number of individual parties. It was clear half-way through the campaign that the Government was destined to fall; no fewer than 
three-quarters of those polled by Nielsen (Kenny 2013), Newspoll (2013) and ReachTEL (2013) in the last week of the campaign knew this. Since 1972 no government had changed hands with less than 52.7 per cent of the two-partypreferred, so no well-informed observer should have expected a two-partypreferred for the Coalition of less than about 53 per cent.

'Robo-polling' by landline, polling via SMS, and polling online also attracted market researchers who lacked media sponsors but wanted to take advantage of the media coverage election polling inevitably generates. Even without a media sponsor, relationships are easily institutionalised: the polls produced by Essential were written up and promoted in the Monday editions of Crikey; JWS's findings were exclusive to the Australian Financial Review even when the paper hadn't paid for them. Pollsters judged to have done well are more likely to generate business opportunities beyond the media than those judged to have done poorly, regardless of whether the media simply reported their polls or commissioned them. Since market research firms depend much more heavily on non-media clients than on media clients, publicity is important.

Anxieties within the industry about the possibility of the polls falling foul of voters who had shifted from landlines to mobiles proved unwarranted. Far from doing badly the traditional CATI polls - Nielsen, Newspoll, and Galaxy - did well. Measured against the two-party-preferred their median error was well inside the long-term (post-1993) median, which in 2010 stood at 1.8 percentage points. Even the average error per party, which was greater than the error on the two-party-preferred, provided no grounds for thinking that the performance of the polls had been affected by the increasing difficulty of reaching respondents who had switched to mobiles - the young, in particular. The relatively poor performance of the final Lonergan poll, conducted via mobiles, will have provided added reassurance. For those who stuck with CATI, the application of standard weighting procedures seems to have done the trick. Anxieties may have been allayed. However, with the rapid growth in the proportion of voters who can only be contacted by mobiles or online, these anxieties will not have been laid aside.

Where the polls ran into most trouble was in marginal seats. For the most part this was a matter of the polls being taken too soon, especially in New South Wales and Queensland, because votes for minor parties or 'flash' parties are more likely to crystallise later in the campaign. It also had to do with the size of samples - in the Morgan case, spectacularly so. Importantly, it was not because of the 'robos' - the records of Newspoll and Morgan, with their very different techniques, were not markedly different (see also Bowe 2013b).

The pollsters' lack of transparency remains a problem. This is most obvious in relation to Galaxy, with its use of mixed modes, and Morgan, which compounded 
the mystery surrounding its use of mixed modes by using its final poll to predict the outcomes in every seat. But the question of transparency transcends issues around modes or how they are combined. What is more remarkable is the similarity of all the two-party-preferred results. Either this is a case of all roads leading to Rome, with different ways of getting there making little difference, or it is a case of pollsters looking over their shoulders to see what their rivals are doing - the 'late mover's advantage' (Goot 2009: 128) or 'herding', as Nate Silver (2012) has called it. While this may be one of the legacies of the campaign which calls for further investigation, it is unlikely that pollsters would allow an investigation of this kind to get very far.

\section{Acknowledgements}

For their assistance in providing data or clarifying their practices, I am grateful to Chris Pyra and Rebecca Tilly of AMR, Peter Lewis of Essential Media Communications, David Briggs of Galaxy Research, John Scales of JMS Research, Chris Lonergan of Lonergan Research, John Stirton of Nielsen, Martin O'Shannessy of Newspoll, James Stewart of ReachTEL, and Vaishali Nagaratnam of Roy Morgan Research. Thanks, too, to Samuel Paske of Enterprise Marketing and Research Services (EMRS), Richard Herr, and Keith Patterson of the Patterson Research Group.

\section{References}

AAP. 2013. 'Exit poll tips coalition landslide'. Business Spectator, 7 September, viewed 13 January 2014: <www.businessspectator.com.au/news/2013/9/7/ election/exit-poll-tips-coalition-landslide $>$.

Aitkin, Don. 1982. Stability and Change in Australian Politics. 2nd edn. Canberra: Australian National University Press.

Allard, Tom. 2013. 'Two states key to Coalition victory'. The Age, 9 September: 6.

Bowe, William. 2013a. 'Random observations'. Crikey, 10 September, viewed 13 January 2014: <blogs.crikey.com.au/pollbludger/2013/09/10/randomobservations $/>$.

Bowe, William. 2013b. 'The verdict is in on pollsters: Coalition bias, electorate polls fail'. Crikey, 2 December, viewed 13 January 2014: <www.crikey.com. $\mathrm{au} / 2013 / 12 / 02 /$ the-verdict-is-in-on-pollsters-coalition-bias-electorate-pollsfail $/>$. 
Bowe, William. 2013c. 'Senate race: polling shows challenge to Greens power'. Crikey, 20 February, viewed 13 January 2014: <www.crikey.com. $\mathrm{au} / 2013 / 02 / 20 /$ senate-race-polling-shows-challenge-to-greens-power/>.

Goot, Murray. 2005. 'The polls: Labor, Liberal or too close to call?'. In Marian Simms and John Warhurst (eds), Mortgage Nation: The 2004 Australian Elections, Perth: API Network and Curtin University of Technology Press.

Goot, Murray. 2009. 'Getting it wrong while getting it right: the polls, the press and the 2007 Australian election'. Australian Cultural History 27(2): 115-33.

Goot, Murray. 2012. 'To the second decimal point: how the polls vied to predict the national vote, monitor the marginals and second-guess the Senate'. In Marian Simms and John Wanna (eds), Julia 2010: The Caretaker Election, Canberra: ANU E-Press.

Goot, Murray. 2014. 'The rise of the robo: media polls in a digital age'. In Essays 2014: Politics, North Melbourne: Australian Scholarly Publishing.

Jackman, Simon. 2005. 'Pooling the polls over an election campaign'. Australian Journal of Political Science 40: 499-517.

Jackman, Simon. 2013. 'Election 2013: how did the polls perform?'. Guardian Australia, 8 September, viewed 13 January 2014: <www.theguardian.com/ world/the-swing/2013/sep/08/election-2013-polls-performance-australia >.

Kenny, Mark. 2013. 'Abbott to sweep aside Labor'. Sydney Morning Herald, 6 September.

Knott, Matthew. 2013. 'Election poll war: landline lives as mobiles fall flat'. Crikey, 9 September, viewed 13 January 2014: <www.crikey.com. au/2013/09/09/election-poll-war-landline-lives-as-mobiles-fall-flat/>.

Lehmann, John. 2013'.Galaxy on the money with polls'. Daily Telegraph, 9 September.

Newspoll. 2013. Poll. 3-5 September, viewed 13 January 2014: <polling. Newspoll.com.au.tmp.anchor.net.au/image_uploads/130922\%20Final\%20 Election \%20Poll.pdf $>$.

Nielsen, 2013. 'Federal poll report', 6 September.

ReachTEL. 2013. '7 News - National Poll-5th September 2013', viewed 13 January 2014: <www.ReachTEL.com.au/blog/7-news-national-poll5 september $13>$. 
Roy Morgan Research. 2013a. 'Roy Morgan-Channel 10SMS Exit Morgan Poll most accurate on 2PP'. 9 September, viewed 15 January 2014: <www.royMorgan. com/findings/5173-federal-election-2013-accuracy-201309090137>.

Roy Morgan Research. 2013b. 'LNP set to win federal election and over 90 seats. High vote for Palmer Party (6.5\% in Queensland), helps the L-NP vote'. 6 September, viewed 15 January 2014: <www.royMorgan.com/findings/5169Morgan-poll-federal-election-2013-201309061457>.

Roy Morgan Research. 2013c. 'Roy Morgan-Channel 10 Exit Poll-1pm'. NewsMaker.com, 8 September, viewed 15 January 2014: <www. newsmaker.com.au/news/27511/roy-Morganchannel-10-exit-poll-1 pm\#. UlpKvBA5Ns4>.

Silver, Nate. 2012. 'Pollsters may be herding'. Votamatic, viewed 13 January 2014: < votamatic.org/pollsters-may-be-herding/>.

Tadros, Edmund. 2013. 'Robots ring changes in election polling'. Australian Financial Review, 9 September: 12.

Tasker, Sarah-Jane. 2013. 'Exit poll shows as protests all hot air'. The Australian, 11 September.

Taylor, Lenore. 2013. 'Labor gains ground on Coalition, says new mobile-only poll'. Guardian Australia, 6 September, viewed 13 January 2014: <www. theguardian.com/world/2013/sep/06/two-party-preferred-vote-narrows $>$.

Textor, Mark. 2013. 'Exit polls on vote. I know of few things more pointless. Wait a few hours. Seriously'. Twitter post, 6 September, viewed 28 September 2013: @markatextor.

YouDecide9. 2013. 'JUST IN: The Coalition has reached the required number of seats to declare victory'. Twitter post, 7 September: @YouDecide9, <twitter. com/YouDecide9/status/376302903213817856/photo/1>. 
This text taken from Abbott's Gambit: The 2013 Australian Federal Election, edited by Carol Johnson and John Wanna, published 2015 by ANU Press, The Australian National University, Canberra, Australia. 